\title{
Antiobesity Potential and Complex Phytochemistry of Momordica charantia Linn. with Promising Molecular Targets
}

\author{
PUSHPA KARALE, S. C. DHAWALE* AND M. A. KARALE \\ Department of Pharmacology, School of Pharmacy, Swami Ramanand Teerth Marathwada University, Nanded-431 606, \\ ${ }^{1}$ Department of Microbiology, Dayanand Science College, Latur-413 512, IndiaPark-II, Greater Noida-201 306, Uttar Pradesh, \\ India
}

\section{Karale et al.: Antiobesity potential of bitter melon}

\begin{abstract}
Momordica charantia L. grows in many tropical and subtropical regions, the fruits of which are gradually becoming popular for treating diabetes and associated diseases. Momordica charantia L. appears to be an inimitable species that synthesizes a diverse range of chemical constituents in the fruits, leaves, stem and roots. Over 248 compounds belonging to the lipids, phenolics and terpenoids classes have been reported in various studies. The cucurbitane types of triterpenes exist in various parts of this plant as aglycones as well as glycosylated forms. Momordica charantia $\mathbf{L}$. has been comprehensively studied worldwide for therapeutic properties to treat a number of diseases like diabetes, dyslipidaemia, obesity and certain cancers. The bitter melon seems to exert lipid lowering and antiobesity effects via several mechanisms like PPARs, LXRs, SREBPs, and Sirts-mediated fat metabolism in various tissues, prevent adipocyte hypertrophy and visceral fat accumulation. This article presents an extensive literature review on the vast potential of bitter melon as antiobesity agent with supporting data on complex phytochemistry.
\end{abstract}

Key words: Obesity, phytochemicals, bitter melon, cucurbitane-type terpenoids

Momordica charantia L. is a tropical or subtropical creeper belonging to family Cucurbitaceae and widely used as a medicinal herb from ancient time (fig. 1). M. Charantia L. or bitter melon, also known as balsam pear or Karela, is a vegetable and common food in Indian cuisine and has been used comprehensively in folk medicine ${ }^{[1]}$. The Latin name Momordica means 'to bite' referring to the serrated edges of the leaf, which appear as if they have been bitten ${ }^{[2]}$. The major regions of M. charantia L. cultivation are Asia including China, India, Sri Lanka and Thailand, Central and South America and North America ${ }^{[3]}$. In Ayurveda, the fruit is considered as tonic, stomachic, stimulant, emetic, antibilous, laxative and alterative ${ }^{[4]}$. Bitter melon has been used in various Asian traditional medicine systems for a long time. It is well recognized, the plant is extensively in use in the Chinese, Ayurvedic and Indonesian systems of medicines as well as in Japan ${ }^{[5]}$.

The therapeutic significance of the plant is symbolized by the fruits which contain about half a dozen seeds per gram of the fresh fruit. As the name implies, the fruits are bitter and bitterness enhance with the level of

*Address for correspondence

E-mail: shashiprathmesh@gmail.com

July-August 2020 maturity and hence earlier harvesting required to battle bitter taste. The leaves and young shoots of bitter melon recognized to be used in traditional medicine as a herbal tea. The range of pharmacological activities reported for bitter melon is rapidly increasing in recent years and its claimed uses and potential applications for cancer and other diseases have been extensively reviewed ${ }^{[3]}$. Likewise, the range of medicinal claims range from diabetes, hypertension, obesity, cancer as well as AIDS.

During the past 2 decades, it has been reported that $M$. charantia L. possessed various beneficial effects, including antiinflammatory ${ }^{[6]}$, antioxidant ${ }^{[7]}$, cytotoxic $^{[8]}$, anticancer ${ }^{[9-11]}$, antiobesity ${ }^{[12]}$, antiviral ${ }^{[13]}$, antiHIV $^{[14]}$, antiulcer ${ }^{[15]}$, cholesterol lowering ${ }^{[16]}$, inhibition of protein tyrosine phosphatase $1 \mathrm{~B}^{[17]}$ and

This is an open access article distributed under the terms of the Creative Commons Attribution-NonCommercial-ShareAlike 3.0 License, which allows others to remix, tweak, and build upon the work non-commercially, as long as the author is credited and the new creations are licensed under the identical terms

Accepted 02 June 2020 Revised 10 March 2020

Received 26 December 2019 Indian J Pharm Sci 2020;82(4):548-561 


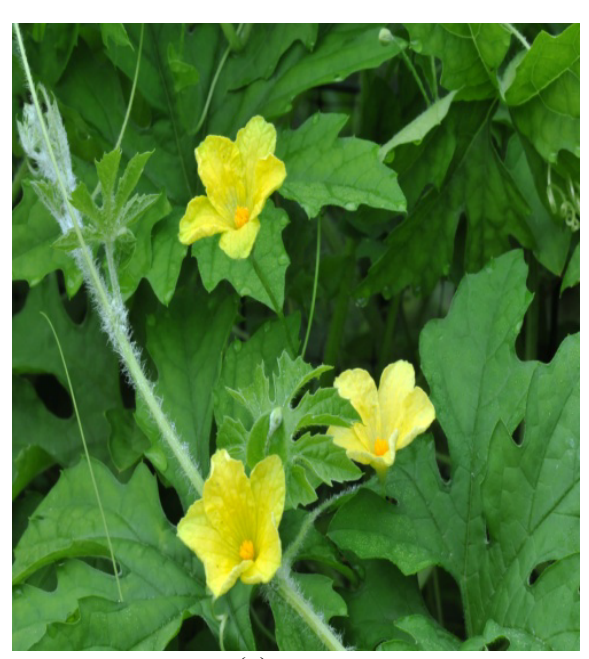

(a)

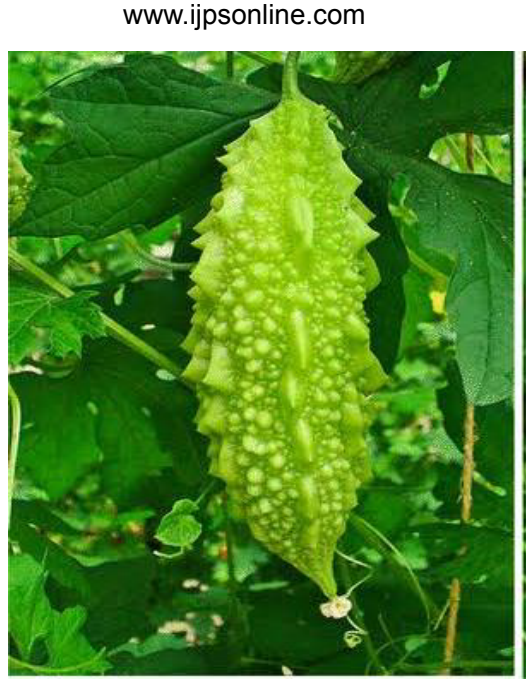

(b)

(c)

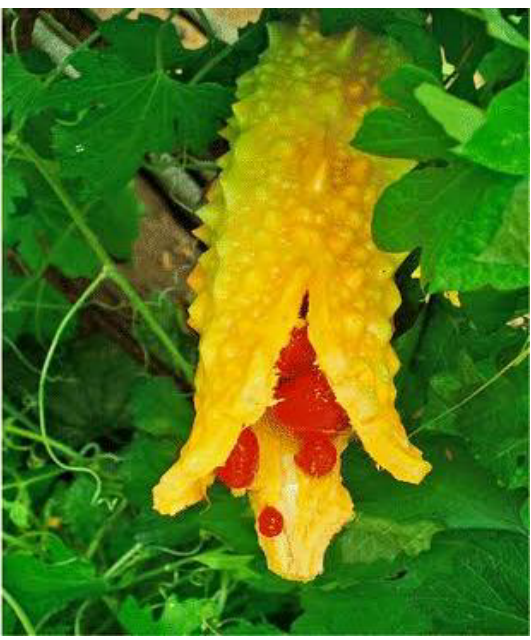

Fig. 1: Plant parts of $M$. charantia $L$.

(a) Leaves; (b) unripe fruit; and (c) ripe fruit and seeds of plant

antiosteoporosis ${ }^{[18]}$. This review aims to highlight the complex phytochemistry and extensive review on antiobesity potential of bitter melon with possible targets.

\section{Botanical description:}

M. charantia L. was known previously by several synonyms including the Cucumis argyi H.Lev., Cucumis intermedius M. Roem., Momordica anthelmintica Schumach. \& Thonn., M. charantia subsp. abbreviata (Ser.) Greb., M. charantia var. abbreviata Ser., M. charantia f. muricata (Willd.)., M. charantia var. muricata (Willd.) Chakrav., M. charantia var. pseudobalsamina Griseb., M. charantia var. zeylanica Hitchc., M. elegans Salisb., M. indica L., M. jagorana K.Koch., M. muricata Willd., M. papillosa Peckolt ex Rosenthal., M. roxburghiana G. Don., M. senegalensis Lam., M. thollonii Cogn., M. zeylanica Mill. The botanical description of different parts of the plant is presented in Table $1^{[19]}$.

Cucurbitaceae family is known to comprise some 101 accepted genera and the genus Momordica L. itself comprises of some 50 accepted species within the family ${ }^{[20]}$. The taxonomic hierarchy of bitter melon within the plant kingdom is as follows: Kingdom: Plantae; Subkingdom: Viridiplantae; Superdivision: Embryophyta; Division: Tracheophyta; Subdivision: Spermatophytina; Class: Magnoliopsida; Super order: Rosanae; Order: Cucurbit ales; Family: Cucurbitaceae; Genus: Momordica Linn.; Species: Momordica charantia L.-balsampear.

The existence of many varieties of bitter melon has been noted ${ }^{[21]}$, for example, it was reported that the fruits of the wild variety of $M$. charantia $\mathrm{L}$. growing in Trinidad and Tobago were of one-fifth in size as compared to the cultivated Indian ones.

\section{Phytochemistry:}

The main constituents of bitter melon are triterpenoids, saponins, protein, polysaccharides, steroids, alkaloids, lipids, and phenolic compounds ${ }^{[22]}$. Several bioactive compounds of $M$. charantia $L$. have been recorded and literature reported that these are responsible for various pharmacological effects as depicted in Table $2^{[23-49]}$.

\section{Triterpenoids:}

The most abundant phytochemical components of bitter melon fruits are the triterpenoid class of secondary metabolites and are well-known for their bitterness and toxicity. These are divided in 2 types primarily the cucurbitane-type and to a less extent oleane-type, which may occur either in their glycosylated or aglycone forms (fig. 2). The fruits are predominant source of terpenoids with great deal of structural diversity but the leaves, stems and roots have also been shown to be good sources of these compounds ${ }^{[23]}$. An extremely large number (193) of cucurbitane-type triterpenes were isolated from bitter melon that exhibited various pharmacological effects (Table 3). The sugar monomers as $\beta$-D-glucopyranosyl, $\beta$-D-allopyranosyl, $\beta$-D-xylopyranosyl occur in cucurbitane-type triterpenes either by their own as O-linked glycosides, or in different combinations as disaccharides or polysaccharides. The rare glycoside in these compounds is the 3-keto-glucoside ${ }^{[50]}$.

Momordicosides A and B were isolated firstly from the seeds of bitter melon fruits ${ }^{[51]}$; while, momordicosides $\mathrm{C}, \mathrm{D}$ and $\mathrm{E}$ were isolated as minor components of 
TABLE 1: BOTANICAL DESCRIPTION OF MOMORDICA CHARANTIA LINN.

\begin{tabular}{|c|c|}
\hline Plant parts & Description \\
\hline \multirow[t]{2}{*}{ Leaves } & $\begin{array}{l}\text { Broadly ovate to orbicular in outline, cordate, narrowly decurrent on to petiole, sparsely pubescent to } \\
\text { densely villous on veins beneath, deeply palmately } 3 \text {-7-lobed, lobes variously sinuate-dentate or lobulate. } \\
\text { Leaf lamina } 10 \times 12.5 \mathrm{~cm} \text {. }\end{array}$ \\
\hline & Flowers are monoecious and solitary. \\
\hline \multirow[t]{2}{*}{ Flowers } & $\begin{array}{l}\text { Male flowers: peduncle } 0.3-5 \mathrm{~cm} \text { long; bract } 2-17 \mathrm{~mm} \text { long, broadly ovate or reniform, sessile, cordate, } \\
\text { amplexicaul, pedicel } 2-9.5 \mathrm{~cm} \text { long. Receptacle-tube } 1-5 \mathrm{~mm} \text { long; lobes } 3-7 \mathrm{~mm} \text { long, ovate-lanceolate. } \\
\text { Petals } 1.0-2.5 \mathrm{~cm} \text { long, pale to deep yellow, ovate to obovate. }\end{array}$ \\
\hline & $\begin{array}{l}\text { Female flowers: peduncle } 0.2-5 \mathrm{~cm} \text { long; bract } 1-12 \mathrm{~mm} \text { long; pedicel } 1-10 \mathrm{~cm} \text { long; ovary } 8-11 \times 2-4 \mathrm{~mm} \text {, } \\
\text { ovoid-rostrate to fusi-form, ridged, pilose on ridges, tuberculate; receptacle-tube } 1-3 \mathrm{~mm} \text { long, lobes } 2-5 \\
\mathrm{~mm} \text { long, lanceolate; petals } 0.7-1.2 \mathrm{~cm} \text { long. }\end{array}$ \\
\hline Fruits & $\begin{array}{l}\text { Fruit } 2.5-4.8 \times 1.5-2.3 \mathrm{~cm} \text {, ovoid-rostrate or ellipsoid, longitudinally ribbed and tuberculate, bright orange- } \\
\text { red, dehiscent into } 3 \text { valves; fruit-stalk } 3.4-15 \mathrm{~cm} \text { long. }\end{array}$ \\
\hline Seeds & $\begin{array}{l}\text { Seeds } 8-11,4.5-8 \times 2-3.5 \mathrm{~mm} \text {, enveloped in sticky red pulp, ovate-elliptic to oblong in outline; faces } \\
\text { flattened, sculptured, with sinuate edges; margins grooved. }\end{array}$ \\
\hline Petiole & Petiole $0.5-7 \mathrm{~cm}$ long. \\
\hline
\end{tabular}

TABLE 2: BIOACTIVE COMPONENTS OF MOMORDICA CHARANTIA LINN. AND THEIR PHARMACOLOGICAL EFFECTS

\begin{tabular}{lccc}
\hline Bioactive compounds & Distribution & Pharmacological effects & References \\
\hline Triterpenoids & Leaves, stem, fruits & Cancer chemo protective, anticancer antioxidant, & {$[23-26]$} \\
Peptides and proteins & Seed & antidiabetic & Antiviral, anti-tumour, immune suppressant, antimicrobial \\
Phenolics & Fruit and seed & Antioxidant, anti-inflammatory, immunostimulant & {$[31-34]$} \\
Saponin & Fruit, root, seed & Antihyperglycemic, hypolipidemic, antiviral, bacteriostatic & {$[35-39]$} \\
Polysaccharide & All parts of plant & Antioxidant, antidiabetic, immune enhancement, & {$[40-44]$} \\
Lipid & Seed & neuroprotective, antitumor & {$[45,46]$} \\
Steroids & Anti-tumor, antioxidant & {$[47-49]$} \\
\hline
\end{tabular}

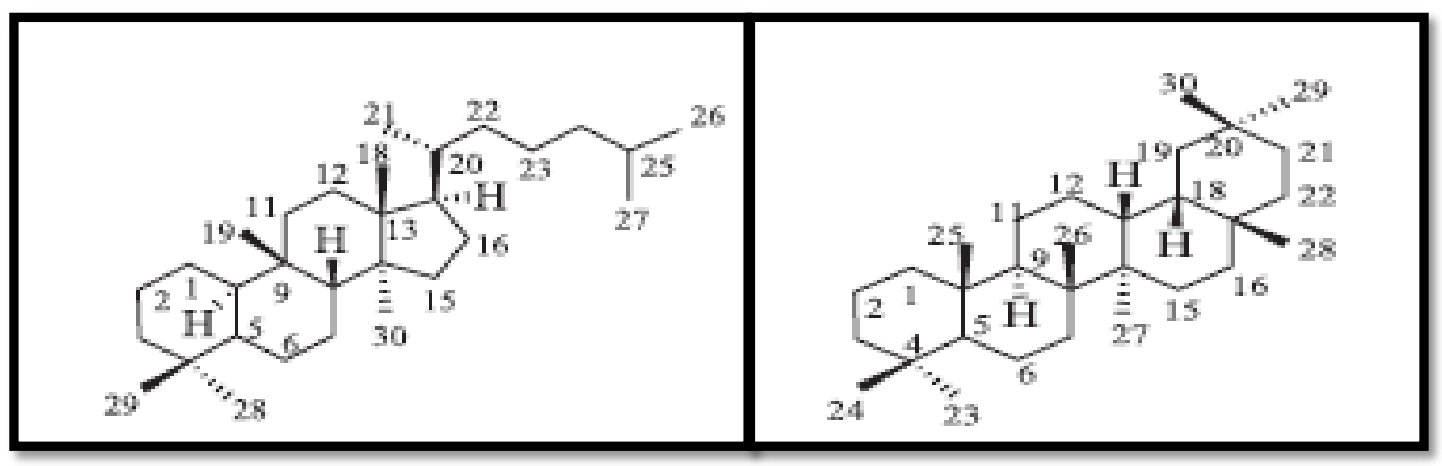

Fig. 2: The cucurbitane and oleane type triterpene skeleton of $M$. charantia $L$.

the seeds ${ }^{[52]}$. The study on the fruits of $M$. charantia L. further added a momordicosides F1, F2, G, I, K and L as novel compounds in previously reported ones ${ }^{[53]}$. The momordicosides I and momordicosides $\mathrm{M}$ along with other compounds have also been isolated from the fruits of bitter melon ${ }^{[54]}$. Further additions of momordicosides $\mathrm{M}-\mathrm{O}$ as new compounds were confirmed by chemical examination of the fresh fruits ${ }^{[5]}$. The Vietnamese origin dried fruits of $M$. charantia had shown existence of an auxiliary three pioneering momordicosides $\mathrm{U}, \mathrm{V}$ and $\mathrm{W}^{[56]}$.
The cucurbitane-type triterpenes, which are known to be responsible for the bitterness of the leaves and vines of the $M$. charantia L. are momordicines ${ }^{[57]}$. The momordicine IV and the malonyl derivative of momordicine II, momordicine $\mathrm{V}$ are readily available in the leaves of bitter melon ${ }^{[58]}$. The isolation of momordicines VI, VII, and VIII were first confirmed from the stems and leaves of bitter melon ${ }^{[59]}$. The goyaglycosides-a, -b, -c, -d, -e, -f, -g, and -h were isolated from the fresh fruits of Japanese $M$. charantia L. ${ }^{[60]}$. A novel compound goyaglycoside I was an 
TABLE 3: CUCURBITANE TYPE OF TRITERPENOIDS OF MOMORDICA CHARANTIA L.

Phytochemical Name Plant parts Chemical structure

Momordicoside A \& B

Fruits and seeds

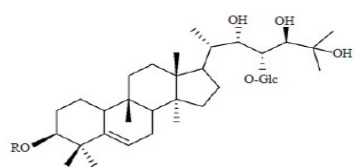

Momordicoside $\mathrm{K}$

Leaves, fruits and roots

Momordicoside I \& F1

Fruits

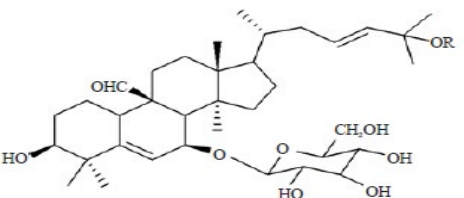

Momordicoside G \& F2 Leaves and fruits

Momordicine I \& II

Leaves, vines and fruits

Goyaglycoside-a \& b Leaves and vines

Goyaglycoside-c \& d

Fruits

Goyaglycoside-e

Fruits

Goyaglycoside- $f$

Fruits

Goyaglycoside-g

Fruits$$
\text { но }
$$

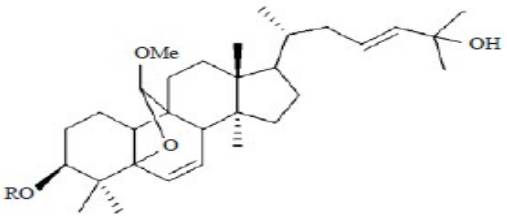

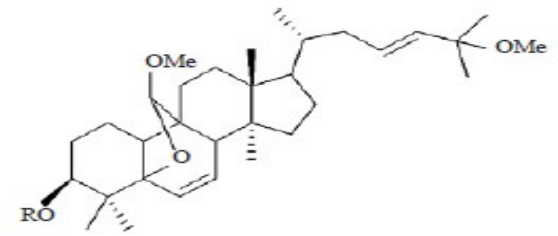

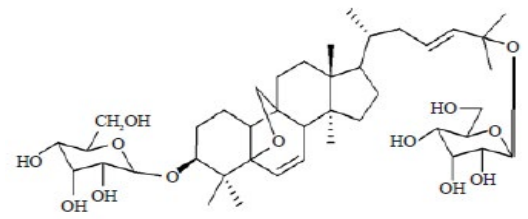

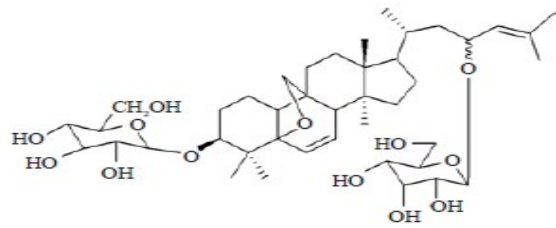

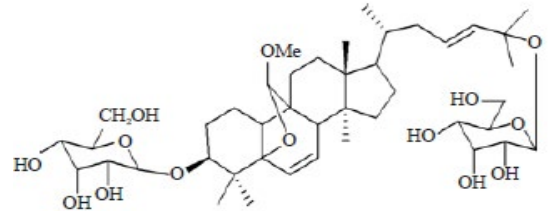
Pharmacological effects

Antidiabetic, antiobesity, anticancer

Antiproliferative, hypoglycemic, antiobesity, antioxidant hypoglycemic, antiobesity, disaccharidase

Antiproliferative, hypoglycemic, antiobesity

Cytotoxic, antiinflammatory, antiviral, immunomodulatory, antioesity

Antiproliferative, hypoglycemic, antiobesity, anticancer

Antiproliferative, hypoglycemic, antiobesity, anticancer

Cytotoxic, antiobesity, antidiabetic

Antiobesity, antidiabetic

Hypoglycemic, antiobesity 


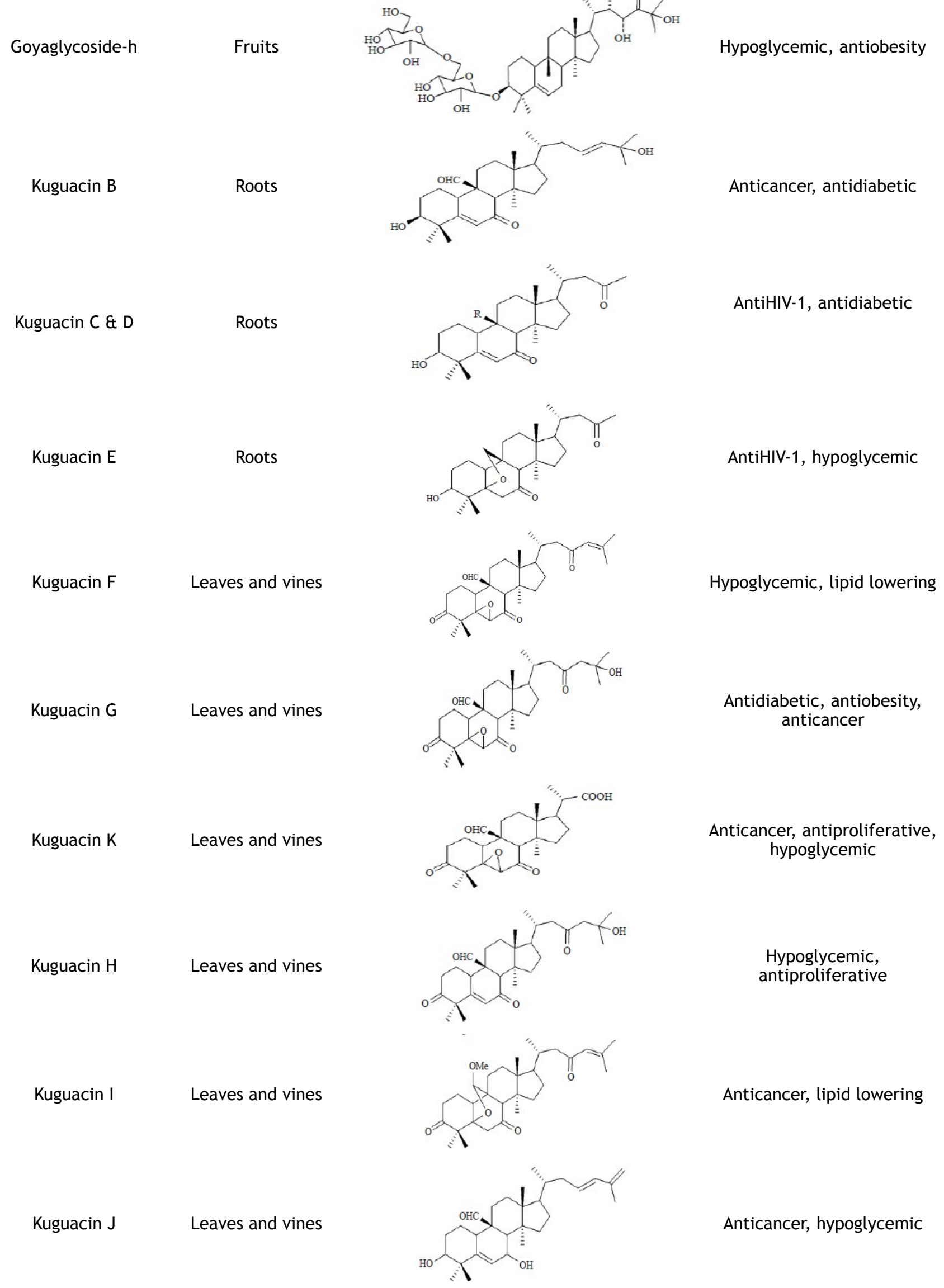


www.ijpsonline.com

Kuguacin $\mathrm{L} \quad$ Leaves and vines

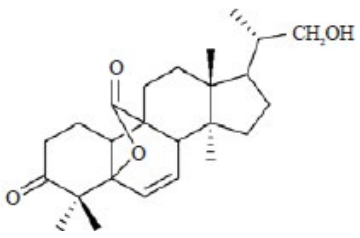

Antiproliferative, hypoglycemic

Kuguacin $M$

Leaves and vines

Kuguacin $\mathrm{P} \& \mathrm{Q}$

Leaves and vines

Kuguacin $\mathrm{R}$

Leaves, stems and fruits
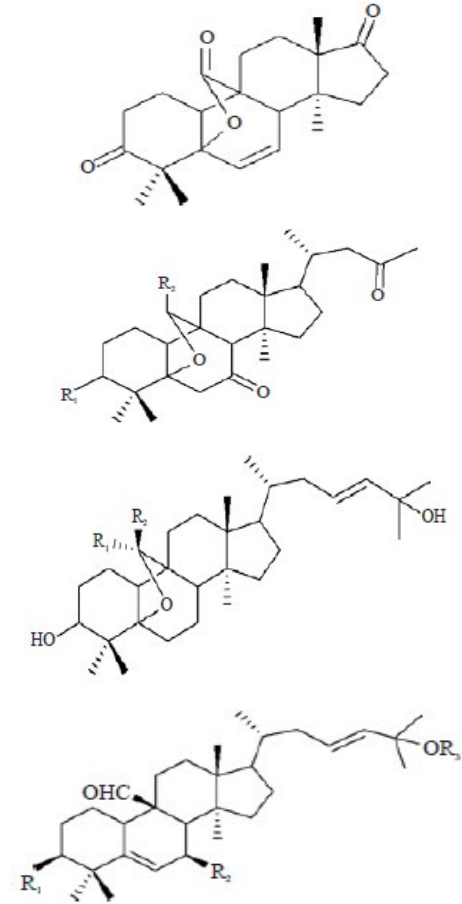

Kuguacin S

Leaves and vines

Charantoside I

Charantoside II

Fruits

Charantoside III

Charantoside IV

Fruits

Fruits

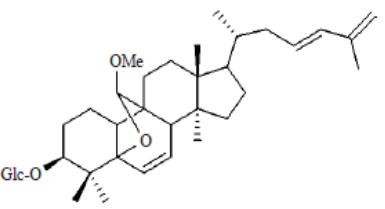<smiles>CC1CCC2CC3CCC2(C=CC3O)C1(C)C</smiles>
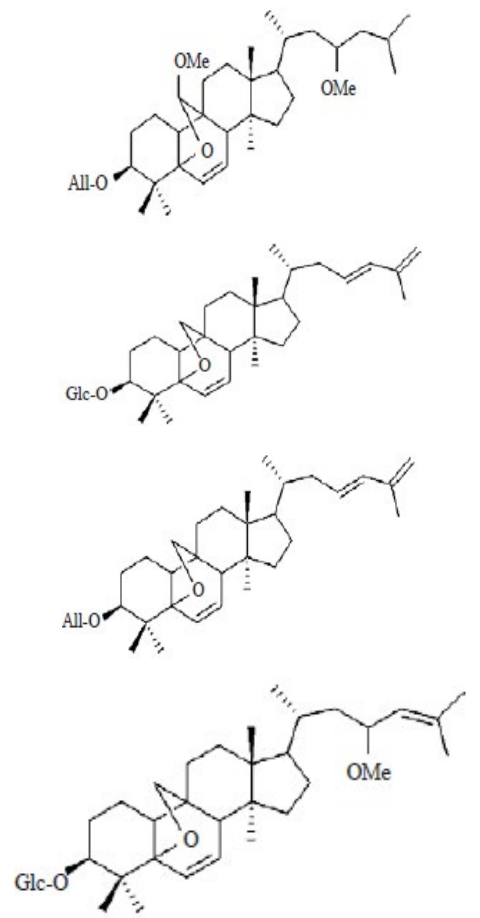

Hypoglycemic, anticancer

Hypoglycemic, antiproliferative

Antioxidant, hypoglycemic, lipid lowering

Lipid lowering, hypoglycemic

Hypoglycemic, Antiobesity

Hypoglycemic, antiobesity

Hypoglycemic, Antiobesity

Hypoglycemic, antiobesity

Hypoglycemic, antiobesity 
Charantoside VII

Fruits

Charantoside VIII

Fruits

Goyasaponin I

Goyasaponin II

Goyasaponin III

Karavilagenin C

Fruits

Karaviloside I, II \& III

Fruits

Kuguaglycoside G

Roots

Momordicinin

Fruits

Fruits

Fruits

Fruits
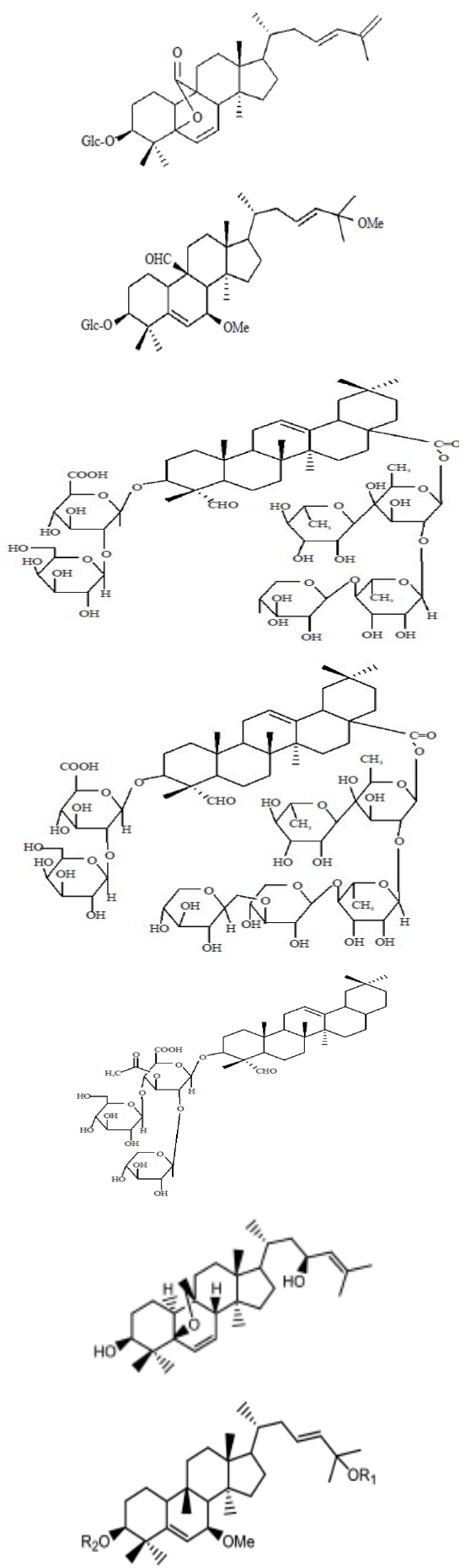

ntiproliferative, antidiabetic, hypolipidemic

Cytotoxic, antiproliferative, hypoglycemic, anticancer

Antidiabetic, antiobesity, lipid lowering 


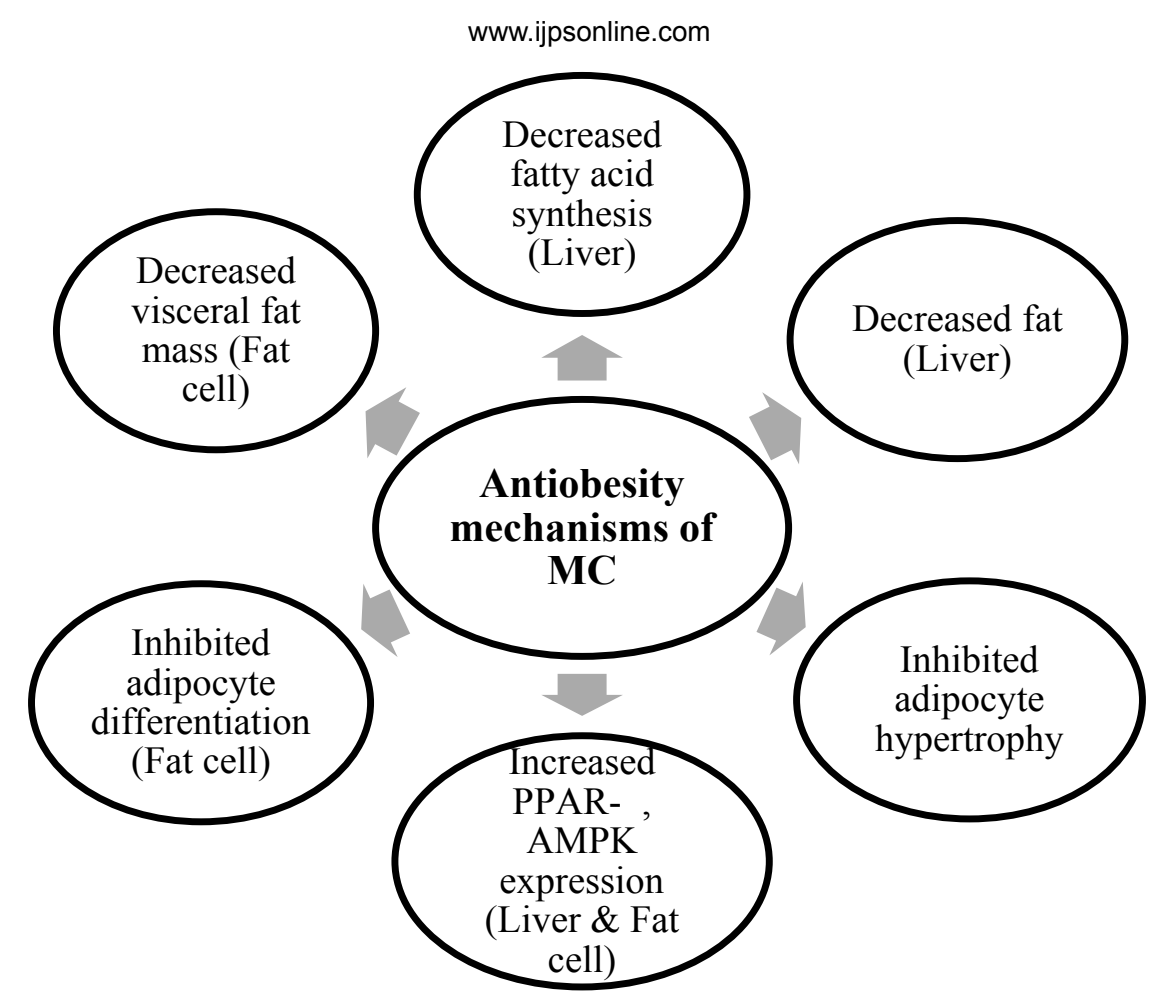

Fig. 3: Probable molecular targets and antiobesity mechanism of Momordica charantia $\mathbf{L}$.

additional triterpene isolated from the immature fruit of bitter melon ${ }^{[61]}$. The novel cucurbitane-type triterpene called karavilagenins A-C and 5 new triterpene glycosides called karavilosides I-V were isolated from the dried fruit of M. charantia $\mathrm{L} .{ }^{[62]}$.

The methanol extracts of the fruits of Japanese $M$. charantia L. showed charantosides I, II, III-VI, VII and VIII, however charantoside IX and X were the other novel compounds reported ${ }^{[63]}$. The 3 novel compounds, charantosides $\mathrm{A}, \mathrm{B}$ and $\mathrm{C}$ were obtained from fruits of bitter melon ${ }^{[22]}$. Another group of interesting triterpenoids are those known by their trivial names kuguacins. kuguacins A-E and kuguacins F-S were isolated from the roots and the leaves of bitter melon plant, respectively ${ }^{[64]}$. Kuguacins II-VI were novel compounds isolated together with various other known compounds from the fruit of M. charantia L. ${ }^{[65]}$. From the aqueous ethanol extracts of fresh fruits 8 novel cucurbitane-type glycosides were isolated, which were named kuguasaponins $\mathrm{A}-\mathrm{H}^{[8]}$. The ethanol extract of fruits of $M$. charantia L. identified 15 cucurbitanetype triterpene glycosides including 4 new compounds, kuguaosides $\mathrm{A}-\mathrm{D}^{[35]}$.

\section{Flavonoids and phenolic compounds:}

A number of phenolic compounds with many biological activities have been isolated from bitter melon including, coumaric, caffeic, and ferulic acids as well as the caffeic acid ester, chlorogenic acid, benzoic, gallic and gentisic acid $^{[66]}$. The major flavonoids and phenolic acids in the dried leaves of bitter melon were also analyzed and found to be rutin, gentisic acid and coumaric acid ${ }^{[67]}$. While the phenolic acids and flavonoids as well as their glycosides could be readily extracted with water, their non-polar derivatives may be present in the oil components of the plant ${ }^{[68]}$.

\section{Other components:}

Other than the bioactive compounds, unsaturated fatty acids, alkaloids, amino acids minerals and vitamins are also present in bitter melon ${ }^{[69-71]}$. The extracts of bitter melon showed the presence of 9 kinds of unsaturated fatty acids ${ }^{[72]}$. It has also been demonstrated that 12 , 13 and 12 fatty acids are found in the young, mature and senescent leaves of $M$. charantia $\mathrm{L}$. representing $87.3,95.25$, and $83.11 \%$ of the total fatty acids ${ }^{[73]}$. The contents of total amino acids and the free amino acids of M. charantia L. were 11.99 and $2.36 \%$ as determined by acid hydrolysis and amino acid analysis ${ }^{[74]}$. In addition, bitter melon is a natural source for vitamins; ascorbic acid was detected in the range of 440-780 $\mathrm{mg}$ in the fruit fraction ${ }^{[75]}$. Vicine, an alkaloidal agent was isolated from the seeds of bitter melon, which is responsible for hypoglycemic activity ${ }^{[76]}$.

\section{Antiobesity and lipid lowering effects:}

The action of bitter melon in lowering fat has been supported by plentiful studies, its effect on the level 
of serum FFAs have been contradictory with some authors showing reduction, some shown same level, and others reported an increased levels. For example, the serum FFAs concentration increased in obese rats treated with bitter melon as reported by Chen et $a l .{ }^{[77]}$. An increased level of TG and LDL-C in the serum that is representative of either overproduction by the liver or defective removal from the circulation or the overall dyslipidaemia in diabetes. It is not clear why bitter melon increases the serum level of FFAs. It may facilitate fat mobilization due to suppression of lipogenesis or lipid deposition. While other studies revealed that $M$. charantia $\mathrm{L}$. could lower the serum and liver TG levels ${ }^{[78]}$. Various experimental studies reported a decrease in serum $\mathrm{TC}$, TG and LDL-C concentrations and an increase in serum high density lipoprotein-cholesterol (HDL-C) by bitter melon ${ }^{[79,80]}$.

The findings of experimental research concluded that $M$. charantia L. might reduce fasting insulin, TG, cholesterol and epididymal fat, which were increased by HFD. The dwindling of insulin resistance, improved glucose tolerance, and increased insulin signaling under HFD-induced insulin-resistance and elevated serum lipids may also been shown by bitter melon. Administration of an aqueous extract of unripe fruits of bitter melon improved glucose and insulin tolerance together with inhibition of plasma apoB-100 and apoB48. An animal study had shown evidence for a potent inhibitor of apoB secretion and TG synthesis as well as plasma lipid and VLDL levels in bitter melon juice ${ }^{[81]}$. Overall many studies on the fruits, seeds and aerial parts of $M$. charantia Linn have shown reduced adiposity, lowered serum insulin and normalized glucose tolerance in rats fed with a HFD. The body weight and visceral fat mass of bitter melon-treated obese rats were shown to be lowered ${ }^{[77,82]}$.

While another study revealed that bitter melon supplementation into HFD notably suppressed the levels of fatty acid synthase (FAS), acetyl-CoA carboxylase-1 (ACC-1), lipoprotein lipase (LPL) and adipocyte fatty acid binding protein ${ }^{[83]}$. Water extract of $M$. charantia $\mathrm{L}$. fruits at a dose of $1 \mathrm{~g} / \mathrm{kg}$ revealed to be effective in improving the obesity-induced hyperglycaemia and hyperleptinemia ${ }^{[84]}$, indicating that bitter melon can reduce insulin resistance, visceral fat accumulation and adipocyte hypertrophy probably by down-regulating the expression of key lipogenic genes or proteins in adipose tissues. Aqueous fruit extract of $M$. charantia L. significantly reduced levels of serum $\mathrm{TG}, \mathrm{TC}, \mathrm{LDL}$ and VLDL at a dose of $350 \mathrm{mg} / \mathrm{kg}$ in experimental rats ${ }^{[85]}$. Numerous animal studies have reported efficacy of bitter melon in ameliorating the weight gain and regulation of lipid metabolism ${ }^{[86,87]}$.

The methanol extract of fruits of bitter melon showed antidiabetic and antihyperlipidemic action during different seasons of the year, this suggested that antidiabetic and hypolipidemic activity of $M$. charantia L. may fluctuate according to the quantity and quality of active constituents during different seasons of the year and reach the peak during spring ${ }^{[88]}$. Bitter melon seed oil had shown significantly decreased in body weight, Lee's index, fat index and adipose size in the HFD mice. Meanwhile, serum FFAs levels returned to normal at a dose of $10 \mathrm{~g} / \mathrm{kg}^{[89]}$. M. charantia L. extracts have antiobesity effects and the ability to modulate lipid prolife of mice fed a HFD by suppressing body weight gain, visceral tissue weight, plasma and hepatic lipid concentrations, and lipid peroxidation along with increasing lipid metabolism. The plasma TG, TC, and LDL-C levels along with hepatic TG and TC concentrations were considerably lowered in HFD-fed mice by M. charantia L. extracts. Also elevated plasma HDL-C levels and fecal TG concentration were shown to be elevated in animals treated with these extracts. The extracts exhibited antiobesity effects in HFD-fed mice by inhibiting lipid peroxidation while increasing lipid metabolism ${ }^{[0]}$. Bitter melon extract showed useful benefit on body weight gain and fat deposition, .3 shows the probable molecular targets for improving obesity. Mechanism of action of $M$. charantia L. extracts for antiobesity effect appeared to be, increasing fatty acid oxidation, which could be responsible for reducing weight; decrease in weight of epididymal white adipose tissue (WAT) and adipose leptin; enhanced hepatic and muscle mitochondrial carnitine palmitoyl transferase-I (CPT-I) and acetyl-CoA dehydrogenase enzyme; prevent adipocyte hypertrophy; reduce visceral fat accumulation through dropping mRNA level of fatty acid synthase, lipoprotein lipase, adipocyte fatty acid binding protein and decreasing the lipogenic genes in adipose tissue; downregulation of PPAR $\gamma$, SREPP and perilipin mRNA gene expression.

Moreover, bitter melon extracts reduced lipid accumulation during differentiation from a preadipocyte to adipocyte and down-regulated PPAR ${ }^{[91]}$. PPAR $\gamma$ is considered the master regulator of adipogenesis during differentiation of pre-adipocyte to adipocyte ${ }^{[92]}$. Bitter melon juice inhibited adipocyte differentiation by reducing PPAR $\gamma$, SREBP, and perilipin mRNA gene expression and by increasing 
lipolysis in primary human adipocyte ${ }^{[93]}$. Another study showed that bitter melon reduced TG and LDL levels and increased HDL levels in high sucrose fed rats ${ }^{[94]}$. Female Zucker rats supplemented with ground bitter melon seeds showed decreased TC and LDL-C and increased HDL-C ${ }^{[95]}$. Several transcriptional regulatory factors like AMPK, PPAR- $\gamma$, and PGC- $1 \alpha$ regulate the mitochondrial biogenesis, which would be a possible way of increasing lipid metabolism and utilization in energy demanding cells and tissues ${ }^{[96,97]}$.

AMPK synchronized PPAR $-\gamma$ and PGC- $1 \alpha$ activation encouraged most of the transcriptional signal to augment fatty acid oxidation and mitochondrial function $^{[98-100]}$. PGC-1 $\alpha$ stimulates mitochondrial biogenesis and respiration in multiple cell types and modulates biological programs normally associated with increased oxidative metabolism. Also decreased plasma level of TGs, cholesterol, and FFA was found in plasma of rats fed a HF diet revealed by bitter melon supplementation due to up regulation and activation of PGC- ${ }^{[101]}$. A recent investigation also reported that increased hepatic AMPK p, AMPK $\alpha 1$, AMPK $\alpha 2$, and Sirt 1 content in HFD-fed mice with supplementation of $1.2 \%$ bitter melon extract ${ }^{[102]}$.

LXRs were first recognized as orphan members of the nuclear receptor plays an important role in lipid and cholesterol metabolism and oxidized derivatives of cholesterol act as ligands for the LXRs. A high cholesterol diet fed mice develop enlarged fatty livers, degeneration of liver cells, high cholesterol levels in liver, and impaired liver function by LXR $\alpha$ knockout ${ }^{[103]}$. The $M$. charantia L. extract supplementation decreased hepatic $\operatorname{LXR} \alpha$, which was responsible for decreased serum TC and LDL-C, HDL-C in high cholesterol diet Wistar rats ${ }^{[104]}$. Bitter melon extract was a potent inhibitor of lipogenesis and stimulator of lipolysis in 3T3-L1 pre-adipocyte shown by researcher. The study shown that increasing the ethanol extract concentration led to a decrease in lipid accumulation in adipocyte both during and after differentiation in adipogenesis assay with a near $50 \%$ reduction $^{[105]}$.

\section{Toxic effects:}

Severe adverse reactions were not reported during short term studies while extensive data on the potential toxic effect of bitter melon are not available. Bitter melon fruits are edible and assumed to be well tolerated, at the same time toxicological evidences were reported to discover its therapeutic potential for diabetes. Two cases of acute intoxication reported after taking bitter melon tea ${ }^{[106]}$. Abdominal pain as a side effect has also been reported in some studies ${ }^{[107]}$. The antifertility and abortifacient effects of the $M$. charantia L. reported in animals also suggests further investigation ${ }^{[108-111]}$. An acute disease favism characterized by hemolytic anemia, in individuals with a hereditary loss of the enzyme glucose-6-phosphatase has been shown by vicine found in fava bean ${ }^{[112]}$. Consequently, the presence of vicine in bitter melon seeds was also suggested to put patients with glucose-6-phosphatase deficiency at risk ${ }^{[113]}$. Although there have been no reports on favism induced by bitter melon, individuals susceptible to the disease should avoid eating the fruit.

Current research is directed to reduce the bitterness of $M$. charantia L. preparations attributes to the triterpene compounds and increasing tolerability by the general public through various formulation approaches. Some recent studies used $\beta$-cyclodextrin at $0.25-2 \%$ concentrations to improve sensory quality, total phenolic content, antioxidant activity and antidiabetic potential of $M$. charantia L. juice ${ }^{[14]}$. Various encapsulation methods of bitter melon extracts along with optimized spray-drying techniques were also scrutinized to obtain the powder ${ }^{[115]}$.

To date, M. charantia L. has been broadly studied globally for its medicinal properties and to treat a number of diseases like diabetes, dyslipidemia, obesity, and certain cancers. Isolated compounds from this plant like cucurbitane type terpenoids, flavonoids and phenolic acid and extracts possess antiobesity potential similar to its crude extracts. The extracts of fruits and different compounds seem to exert their beneficial effects via several mechanisms like PPARs, LXRs and SREBPs mediated fat metabolism in various tissues, reduces visceral fat accumulation and adipose hypertrophy. These mechanisms will be directly related to controlling and treating diabetes mellitus, dyslipidemia, obesity and related cardiovascular complications. Thus, further studies are required to conduct more double blind randomized trials with bitter melon extracts in obese population. Numerous in vitro studies have also been employed to demonstrate these effects and further establish. In this review, we summarized phytoconstituents of bitter melon and its antiobesity potential with mechanism of action. This compilation of phytochemicals and antiobesity activity of $M$. charantia L. would help the researchers in dereplication and designing new untried strategies.

\section{REFERENCES}

1. Habicht SD, Kind V, Rudloff S, Borsch C, Mueller AS, Pallauf 
J, et al. Quantification of antidiabetic extracts and compounds in bitter gourd varieties. Food Chem 2011;126:172-76.

2. Subratty AH, Gurib-Fakim A, Mahomoodally F. Bitter melon: An exotic vegetable with medicinal values. Nutr Food Sci 2005;35:143-47.

3. Grover JK, Yadav SP. Pharmacological actions and potential uses of Momordica charantia: A review. J Ethnopharmacol 2004;93:123-32.

4. Bailey CJ, Day C, Turner SL, Leatherdale BA. Cerasee: a traditional treatment for diabetes. Studies in normal and streptozotocin diabetic mice. Diabetes Res 1985;2:81-4.

5. Raman A, Lau C. Anti-diabetic properties and phytochemistry of Momordica charantia L. (Cucurbitaceae). Phytomedicine 1996;2:349-62.

6. Manabe M, Takenaka R, Nakasa T, Okinaka O. Induction of anti-inflammatory responses by dietary Momordica charantia L. (bitter gourd), Biosci. Biotechnol Biochem 2003;67(12):2512-17.

7. Shan B, Xie JH, Zhu JH, Peng Y. Ethanol modified supercritical carbon dioxide extraction of flavonoids from Momordica charantia $\mathrm{L}$. and its antioxidant activity. Food Bioprod Process 2012;90(3):579-87.

8. Zhang LJ, Liaw CC, Hsiao PC, Huang HC, Lin MJ, Lin ZH, et al. Cucurbitane-type glycosides from the fruits of Momordica charantia and their hypoglycaemic and cytotoxic activities. J Funct Foods 2014;6:564-74.

9. Ganguly C, De S, Das S. Prevention of carcinogen-induced mouse skin papilloma by whole fruit aqueous extract of Momordica charantia, Eur J Cancer Prev 2000;9(4):283-88.

10. Li CJ, Tsang SF, Tsai CH, Tsai HY, Chyuan JH, Hsu HY. Momordica charantia extract induces apoptosis in human cancer cells through caspase-and mitochondria-dependent pathways. Evid Based Complement Altern Med 2012;261971.

11. Nerurkar P, Ray RB. Bitter melon: antagonist to cancer. Pharm Res 2010;27(6):1049-53.

12. Chan LL, Chen QX, Go AG, Lam EKY, Li ET. Reduced adiposity in bitter melon (Momordica charantia)-fed rats is associated with increased lipid oxidative enzyme activities and uncoupling protein expression. J Nutr 2005;135(11):2517-23.

13. Puri M, Kaur I, Kanwar R, Gupta R, Chauhan A, Kanwar J. Ribosome inactivating proteins (RIPs) from Momordica charantia for anti-viral therapy. Curr Mol Med 2009;9(9):108094.

14. Fang EF, Ng TB. Bitter gourd (Momordica charantia) is a cornucopia of health: a review of its credited antidiabetic, antiHIV, and anti-tumor properties. Curr Mol Med 2011;11(5):41736.

15. Alam S, Asad M, Asdaq SMB, Prasad VS. Antiulcer activity of methanolic extract of Momordica charantia L. in rats. J Ethnopharmacol 2009;123(3):464-9.

16. Jayasooriya AP, Sakono M, Yukizaki C, Kawano M, Yamamoto K, Fukuda N. Effects of Momordica charantia powder on serum glucose levels and various lipid parameters in rats fed with cholesterol-free and cholesterol-enriched diets. J Ethnopharmacol 2000;72(1):331-6.

17. Zeng K, He YN, Yang D, Cao JQ, Xia XC, Zhang SJ, et al. New compounds from acid hydrolyzed products of the fruits of Momordica charantia L. and their inhibitory activity against protein tyrosine phosphatas1B. Eur J Med Chem 2014;81:17680.

18. Yang ZG, Shi WZ, Shen ZG, Zhang YP, Yang J. Preventive Effect of Momordica charantia L. saponins on osteoporosis in ovariectomized rats. Food Sci 2010;31(7):272-5.
19. Momordica charantia L. Plants of the World online. [cited 30 Dec 2018] Available from: http://powo.science.kew.org/ taxon/urn:lsid:ipni.org:names:293413-1.

20. Joseph B, Jini D. Antidiabetic effects of Momordica charantia (bitter melon) and its medicinal potency. Asian Pac J Trop Dis 2013;3(2):93-102

21. Svobodova BB, Calhelha L, Heleno RC, Alves S, Walcott MJ. Bioactive properties and phenolic profile of Momordica charantia L. medicinal plant growing wild in Trinidad and Tobago. Ind Crop Prod 2017;95:365-73.

22. Shuo J, Mingyue S, Zhang F, Xie J. Recent Advances in Momordica charantia: Functional Components and Biological Activities. Int J Mol Sci 2017;18:2555.

23. Akihisa T, Higo N, Tokuda H, Ukiya M, Akazawa H, Tochigi $\mathrm{Y}$, et al. Cucurbitane-type triterpenoids from the fruits of Momordica charantia and their cancer chemopreventive effects. J Nat Prod 2007;70:1233-9.

24. Agrawal RC, Beohar T. Chemo preventive and anticarcinogenic effects of Momordica charantia extract. Asian Pac J Cancer Prev 2010;11:371-5.

25. Liu $\mathrm{CH}$, Yen MH, Tsang SF, Gan KH, Hsu HY, Lin CN. Antioxidant triterpenoids from the stems of Momordica charantia. Food Chem 2010;118:751-6.

26. Chou CH, Liao MH, Chen TM, Cheng CH, Anggriani R, Tsai $\mathrm{CP}$ et al. Bitter melon triterpenes work as insulin sensitizers and insulin substitutes in insulin-resistant cells. J Funct Foods 2015;13:214-24.

27. Upadhyay A, Agrahari P, Singh DK. A review on salient pharmacological features of Momordica charantia. Int J Pharmacol 2015;11:405-13.

28. Meng Y, Liu S, Li J, Meng Y, Zhao X. Preparation of an antitumor and antivirus agent: Chemical modification of $\alpha$-MMC and MAP30 from Momordica charantia L. with covalent conjugation of polyethyelene glycol. Int J Nanomed 2012;7:3133.

29. Leung SO, Yeung HW, Leung KN. The immunosuppressive activities of two abortifacient proteins isolated from the seeds of bitter melon (Momordica charantia). Immunopharmarcology 1987;13:159-71.

30. Jabeen $U$, Khanum A. Isolation and characterization of potential food preservative peptide from Momordica charantia L. Arabian J Chem 2017;10:S3982-9.

31. Anila L, Vijayalakshmi NR. Beneficial effects of flavonoids from Sesamum indicum, Emblica officinalis and Momordica charantia. Phytother Res 2000;14:592-5.

32. Qader SW, Abdulla MA, Chua LS, Najim N, Zain MM, Hamdan S. Antioxidant, total phenolic content and cytotoxicity evaluation of selected Malaysian plants. Molecules 2011;16:3433-43.

33. Bajpai M, Pande A, Tewari SK, Prakash D. Phenolic contents and antioxidant activity of some food and medicinal plants. Int J Food Sci Nutr 2005;56:287-91.

34. Lin JY, Tang CY. Determination of total phenolic and flavonoid contents in selected fruits and vegetables, as well as their stimulatory effects on mouse splenocyte proliferation. Food Chem 2007;101:140-7.

35. Hsiao PC, Liaw CC, Hwang SY, Cheng HL, Zhang LJ, Shen $\mathrm{CC}$, et al. Anti-proliferative and hypoglycemic cucurbitanetype glycosides from the fruits of Momordica charantia. J Agric Food Chem 2013;61:2979-86.

36. Keller AC, Ma J, Kavalier A, He K, Brillantes AMB, Kennelly EJ. Saponins from the traditional medicinal plant Momordica 
charantia stimulate insulin secretion in vitro. Phytomedicine 2011;19:32-7.

37. Ng TB, Wong CM, Li WW, Yeung HW. A steryl glycoside fraction from Momordica charantia seeds with an inhibitory action on lipid metabolism in vitro. Biochem Cell Biol 1986;64:766-71.

38. Xia K, Yan F, Ye Y, Tang L. The effect of the total saponin extract from the seeds of Momordica charantia L. on anti-virus HSV-I and RSV activity. J Sichuan Univ 2007;1:27.

39. Zhang LY, Wang YT, Geng LJ. Bacteriostatic Activity of Total Saponins from Balsam Pear (Momordica charantia) against Staphylococcus aureus. J Microbiol 2011;1:012.

40. Xu X, Shan B, Liao CH, Xie JH, Wen PW, Shi JY. Antidiabetic properties of Momordica charantia L. polysaccharide in alloxan-induced diabetic mice. Int $\mathrm{J}$ Biol Macromol 2015;81:538-43.

41. Zhang F, Lin L, Xie J. A mini-review of chemical and biological properties of polysaccharides from Momordica charantia. Int J Biol Macromol 2016;92:246-53.

42. Deng YY, Yi Y, Zhang LF, Zhang RF, Zhang Y, Wei ZC, et al. Immunomodulatory activity and partial characterization of polysaccharides from Momordica charantia. Molecules 2014;19:13432-47.

43. Duan ZZ, Zhou XL, Li YH, Zhang F, Li FY, Su-Hua Q. Protection of Momordica charantia polysaccharide against intracerebral hemorrhage-induced brain injury through JNK3 signaling pathway. J Recept Signal Transduct 2015;35:523-9.

44. Cai Y, Liu M, Wu X, Wang Z, Liang C, Yang Y. Study on the antitumor and immune-stimulating activity of polysaccharide from Momordica charantia. Pharm Clin Res 2010;18:131-4.

45. Dhar P, Chattopadhyay K, Bhattacharyya D, Roychoudhury A, Biswas A, Ghosh S. Antioxidative effect of conjugated linolenic acid in diabetic and non-diabetic blood: An in vitro study. J Oleo Sci 2007;56:19-24.

46. Tsuzuki T, Tokuyama Y, Igarashi M, Miyazawa T. Tumor growth suppression by eleostearic acid, a linolenic acid isomer with a conjugated triene system, via lipid peroxidation. Carcinogenesis 2004;25:1417-25.

47. Saeed S, Tariq P. Antibacterial activities of Mentha piperita, Pisum sativum and Momordica charantia. Pak J Bot 2005;37:997.

48. Begum S, Ahmed M, Siddiqui BS, Khan A, Saify ZS, Arif M. Triterpenes, a sterol and a monocyclic alcohol from Momordica charantia. Phytochemistry 1997;44:1313-20.

49. Guevara AP, Lim-Sylianco CY, Dayrit FM, Finch P. Acyl glucosyl sterols from Momordica charantia. Phytochemistry 1989;28:1721-4.

50. Chang CI, Chen CR, Liao YW, Cheng YW, Chen YC, Chou CH. Cucurbitane-type triterpenoids from Momordica charantia. J Nat Prod 2006;69(8):1168-71.

51. Okabe H, Miyahara Y, Yamauchi T, Mirahara K, Kawasaki T. Studies on the constituents of Momordica charantia L. I. Isolation and characterization of momordicosides A ang B, glycosides of a pentahydroxy cucurbitane triterpene. Chem Pharm Bull 1980;28:2753-62.

52. Miyahara Y, Okasbe H, Yamauchi T. Studies on the constituents of Momordica charantia L. II. Isolation and characterization of minor seed glycosides, momordicosides C, D and E. Chem Pharm Bull 1981;29:1561-6.

53. Okabe H, Miyahara Y, Yamauchi T. Structures of momordicosides F1, F2, G, I, K and L, novel cucurbitacins in the fruits of Momordica charantia L. Tetrahedron Lett 1982a; 23(1):77-80.
54. Nhiem NX, Kiem PV, Minh CV, Ban NK, Cuong NX, Tung NH. Alpha-Glucosidase inhibition properties of cucurbitanetype triterpene glycosides from the fruits of Momordica charantia. Chem Pharm Bull 2010;58(5):720-4.

55. Li QY, Liang H, Chen HB, Wang B, Zhao YY.A new cucurbitane triterpenoid from Momordica charantia. Chin Chem Lett 2007; 18(7):843-5.

56. Nguyen XN, Phan VK, Chau VM, Ninh KB, Nguyen XC, Le MH. Cucurbitane-type triterpene glycosides from the fruits of Momordica charantia. Magn Reson Chem 2010; 48:392-6.

57. Okabe H, Miyahara Y, Yamauchi T. Structures of momordicine I, II and III. The bitter principles in the leaves and vines of Momordica charantia L. Chem Pharm Bull 1982b;30:4334-40.

58. Kashiwagi T, Mekuria DB, Dekebo A, Sato K, Tebayashi $\mathrm{S}$, Kim CS. A new ovi position deterrent to the leaf miner, Liriomyza trifolii: cucurbitane glucoside from Momordica charantia. Z Naturforsch C 2007;62(7-8):603-7.

59. Zhao GT, Liu JQ, Deng YY, Li HZ, Qiu MH. Cucurbitanetype triterpenoids from the stems and leaves of Momordica charantia. Fitoterapia 2014;95:75-82.

60. Murakami T, Emoto A, Matsuda H, Yoshikawa M. Medicinal foodstuffs XXI. Structures of new cucurbitane-type triterpene glycosides, goyaglycosides-a,-b, -c, -d, -e, -f, -g, and -h, and new oleanane-type triterpene saponins, goyasaponins I, II, and III, from the fresh fruit of Japanese Momordica charantia L. Chem Pharm Bull 2001;49:54-63.

61. Yue J, Sun Y, Xu J, Cao J, Zhao Y. Cucurbitane triterpenoids from the fruit of Momordica charantia L. and their antihepatic fibrosis and anti-hepatoma activities. Phytochemistry 2019; 157:21-7.

62. Nakamura S, Murakami T, Nakamura J, Kobayashi $H$, Matsuda H, Yoshikawa M. Structures of new cucurbitane-type triterpenes and glycosides, karavilagenins and karavilosides, from the dried fruit of Momordica charantia L. in Sri Lanka. Chem Pharm Bull 2006;54:1545-50.

63. Yue J, Xu J, Cao J, Zhang X, Zhao Y. Cucurbitane triterpenoids from Momordica charantia L. and their inhibitory activity against $\alpha$-glucosidase, $\alpha$-amylase and protein tyrosine phosphatase 1B (PTP1B). J Funct Foods 2017;37:624-31.

64. Chen JC, Liu WQ, Lu L, Qiu MH, Zheng YT, Yang LM. Kuguacins F-S, cucurbitane triterpenoids from Momordica charantia. Phytochemistry 2009;70(1):133-40.

65. Chen JC, Lau CBS, Chan JYW, Fung KP, Leung PC, Liu JQ et al. The Antigluconeogenic activity of Cucurbitacins from Momordica charantia. Planta Med 2015;81(4):327-32.

66. Horax R, Hettiarachchy N, Chen P. Extraction, quantification, and antioxidant activities of phenolics from pericarp and seeds of bitter melons (Momordica charantia) harvested at three maturity stages (immature, mature, and ripe). J Agric Food Chem 2010;58:4428-33.

67. Zhang M, Hettiarachchy NS, Horax R, Chen P, Over KF. Effect of maturity stages and drying methods on the retention of selected nutrients and phytochemicals in bitter melon (Momordica charantia) leaf. J Food Sci 2009;74(6):C441-8.

68. Minh NP. Extraction of polyphenol in bitter melon (Momordica charantia). IJMRD 2014;1(4):115-25.

69. Chuang CY, Hsu C, Chao CY, Wein YS, Kuo YH, Huang CJ. Fractionation and identification of 9c, 11t, 13t-conjugated linolenic acid as an activator of PPAR in bitter gourd (Momordica charantia L.). J Biomed Sci 2006;13:763-72.

70. Krawinkel MB, Keding GB. Bitter gourd (Momordica charantia): A dietary approach to hyperglycemia. Nutr Rev 2006;64:331-7. 
71. Lucas EA, Dumancas GG, Smith BJ, Clarke SL, Arjmandi BH. Health benefits of bitter melon (Momordica charantia). Bioact Foods Promot Health 2010;35:525-49.

72. Kenny O, Smyth TJ, Hewage CM, Brunton NP. Antioxidant properties and quantitative UPLC-MS analysis of phenolic compounds from extracts of fenugreek (Trigonella foenumgraecum) seeds and bitter melon (Momordica charantia) fruit. Food Chem 2013;141:4295-302.

73. Sarkar N, Mukherjee A, Barik A. Olfactory responses of Epilachna dodecastigma (Coleoptera: Coccinellidae) to longchain fatty acids from Momordica charantia leaves. Arthropod Plant Interact 2013;7:339-48.

74. Ke LJ, Lu W, Chang JL, Yuan FY, Rao PF, Zhou JW. Effects of heat drying process on amino acid content of Momordica charantia L. Amino Acids Biol Resour 2010;32:14-6.

75. Han C, Zuo J, Wang Q, Xu L, Wang Z, Dong H, Gao L. Effects of 1-MCP on post harvest physiology and quality of bitter melon (Momordica charantia L.). Sci Hortic Ansterdam 2015;182:86-91.

76. Handa G, Singh J, Sharma ML, Kaul A, Zafar R. Hypoglycaemic principle of Momordica charantia seeds. Nat Prod 1990;6(1):16-9.

77. Chen Q, Chan LL, Li ET. Bitter melon (Momordica charantia) reduces adiposity, lowers serum insulin and normalizes glucose tolerance in rats fed a high fat diet. J Nutr 2003;133:1088-93.

78. Wehash FE, Abpo-Ghanema II, Saleh RM. Some physiological effects of Momordica charantia and Trigonella foenumgraecum extracts in diabetic rats as compared with cidophage ${ }^{\circledR}$. World Acad Sci Eng Technol 2012;64:1206-14.

79. Yuan XQ, Gu XH, Tang J, Wasswa J. Hypoglycemic effect of semi purified peptides from Momordica charantia L. Var. abbreviata Ser. in alloxan-induced diabetic mice. J Food Biochem 2008;32:107-21.

80. Mohammady I, Elattar S, Mohammed S, Ewais M. An evaluation of anti-diabetic and anti-lipidemic properties of Momordica charantia (bitter melon) fruit extract in experimentally induced diabetes. Life Sci J 2012;9(2):363-74.

81. Nerurkar PV, Lee YK, Motosue M, Adeli K, Nerurkar VR. Momordica charantia (bitter melon) reduces plasma apolipoprotein B-100 and increases hepatic insulin receptor substrate and phosphoinositide-3 kinase interactions. Br J Nutr 2008;100:751-9.

82. Chen Q, Li ET. Reduced adiposity in bitter melon (Momordica charanita) fed rats is associated with lower tissue triglyceride and higher plasma catecholamines. Br J Nutr 2005;93:747-54.

83. Huang HL, Hong YW, Wong YH, Chen YN, Chyuan JH, Huang CJ. Bitter melon (Momordica charantia L.) inhibits adipocyte hypertrophy an down regulates lipogenic gene expression in adipose tissue of dietinduced obese rats. Br J Nutr 2008;99:230-9.

84. Shih CC, Lin CH, Lin WL. Effects of Momordica charantia on insulin resistance and visceral obesity in mice on high-fat diet. Diabetes Res Clin Pract 2008;81:134-43.

85. Rajalakshmi A, Senthikumar B, Devi K. Antihyperglycemic and antihyperlipidemic effect of aqueous fruit extract of Momordica charantia against alloxan induced diabetic rats. Int J Pharma Res Sch 2013;2(4):54-60.

86. Fernandes NP, Lagishett CV, Panda VS, Suresh RN. An experimental evaluation of the antidiabetic and antilipidemic properties of a standardized Momordica charantia fruit extract. BMC Complement Altern Med 2007;7:29.

87. Thenmozhi AJ, Subramanian P. Momordica charantia (bitter melon) decreases serum/tissue lipid parameters in hyper- ammonemic rats. Int $\mathrm{J}$ Nutr Pharmacol Neurol Dis 2013; 3 : 249-53.

88. Kolawole OT, Ayankunle AA. Seasonal variation in the antiDiabetic and hypolipidemic effects of Momordica charantia fruit extract in rats. Eur J Med Plants 2012;2(2):177-85.

89. Li X, Yi X, Shuang W, Qianchun D, Chun-Yan W, XiangTao C, et al. Novel bitter melon extracts highly yielded from supercritical extraction reduce the adiposity through the enhanced lipid metabolism in mice fed a high fat diet. J Nutr Inter Metabol 2016;6:26-32.

90. Wang J, Ho KR. The effects of Momordica charantia on obesity and lipid profiles of mice fed a high-fat diet. Nutr Res Pract 2015;9(5):489-95.

91. Popovich DG, Li L, Zhang W. Bitter melon (Momordica charantia) triterpenoid extract reduces preadipocyte viability, lipid accumulation and adiponectin expression in 3T3-L1 cells. Food Chem Toxicol 2010;48(6):1619-26.

92. Wakabayashi KI, Okamura M, Tsutsumi S. The peroxisome proliferator-activated receptor $\gamma /$ retinoid $\mathrm{X}$ receptor $\alpha$ heterodimer targets the histone modification enzyme PRSet7/ Setd8 gene and regulates adipogenesis through a positive feedback loop. Mol Cell Biol 2009;29(13):3544-55.

93. Nerurkar PV, Lee YK, Nerurkar VR. Momordica charantia (bitter melon) inhibits primary human adipocyte differentiation bymodulating adipogenic genes. BMC Complement Altern Med 2010;10:34.

94. Chaturvedi P, George S. Momordica charantia maintains normal glucose levels and lipid profiles and prevents oxidative stress in diabetic rats subjected to chronic sucrose load. J Med Food 2010;13(3):520-7.

95. Gadang V, Gilbert W, Hettiararchchy N, Horax R, Katwa L, Devareddy L. Dietary bitter melon seed increases peroxisome proliferator-activated receptor- $\gamma$ gene expression in adipose tissue, down-regulates the nuclear factor- $\kappa \mathrm{B}$ expression, and alleviates the symptoms associated with metabolic syndrome. J Med Food 2011;14(1-2):86-93.

96. Puigserver P, Spiegelman BM. Peroxisome proliferator activated receptor- $\gamma$ coactivator $1 \alpha$ (PGC- $1 \alpha)$ : transcriptional coactivator and metabolic regulator. Endocrine Rev 2003;24(1):78-90.

97. Vega RB, Huss JM, Kelly DP. The coactivator PGC-1 cooperates with peroxisome proliferator-activated receptor alpha in transcriptional control of nuclear genes encoding mitochondrial fatty acid oxidation enzymes. Mol Cell Biol 2000;20(5):1868-76.

98. Hock MB, Kralli A. Transcriptional control of mitochondrial biogenesis and function. Ann Rev Physiol 2009;71:177-203.

99. Zhang BB, Zhou G, Li C. AMPK: an emerging drug target for diabetes and the metabolic syndrome. Cell Metabol 2009;9(5):407-16.

100. Canto C, Auwerx J. PGC-1 $\alpha$, SIRT1 and AMPK, an energy sensing network that controls energy expenditure. Curr Opin Lipidol 2009;20(2):98-105.

101. Ching RHH, Yeung LOY, Tse IMY, Sit WH, Li ETS. Supplementation of bitter melon to rats fed a high-fructose diet during gestation and lactation ameliorates fructose-induced dyslipidemia and hepatic oxidative stress in male offspring. J Nutr 2011;141(9):1664-72.

102. Yu Y, Zhang XH, Ebersole B, Ribnicky D, Wang ZQ. Bitter melon extract attenuating hepatic steatosis may be mediated by FGF21 and AMPK/Sirt1 signaling in mice. Sci Rep 2013;3:3142.

103. Peet DJ, Turley SD, Ma W. Cholesterol and bile acid 
metabolism are impaired in mice lacking the nuclear oxysterol receptor LXR $\alpha$. Cell 1998;93(5):693-704.

104. Matsui S, Yamane T, Takita T, Oishi Y, Kobayashi-Hattori K. The hypocholesterolemic activity of Momordica charantia fruit ismediated by the altered cholesterol- and bile acidregulating gene expression in rat liver. Nutr Rese 2013;33(7):580-5.

105. Chikkavadaragudi RS, Vishwanath P, Prashant A, Rangaswamy C, Maduvanahalli NS, Hattur B. Fifty percent ethanolic extract of Momordica charantia inhibits adipogenesis and promotes adipolysis in 3T3-L1 pre-adipocyte cells. Rep Biochem Mol Biol 2017;6(1):23-32.

106. Hulin A. Intoxication aigue par Momordica charantia (sorrossi). A propos de deux cas (acute intoxication due to Momordica charantia (sorrossi). Study of two cases). Sem Hop 1988;64:2847-8.

107. Dans AM, Villarruz MV, Jimeno CA, Javelosa MA, Chua J, Bautista R. The effect of Momordica charantia capsule preparation on glycemic control in type 2 diabetes mellitus needs further studies. J Clin Epidemiol 2007;60:554-9.

108. Dixit VP, Khanna P, Bhargava SK. Effects of Momordica charantia L. fruit extract on the testicular function of dog. Planta Med 1978;34:280-6.
109. Saksena SK. Study of antifertility activity of the leaves of Momordica Linn (Karela). Indian J Physiol Pharmacol 1971;15:79-80.

110. Stepka W. Antifertility investigations on Momordica. Lloydia 1974;37:645.

111. Chan WY, Tam PP, Yeung HW. The termination of early pregnancy in the mouse by $\beta$-momorcharin. Contraception 1984;29:91-100.

112. Basch WE, Gabardi S, Ulbricht C. Bitter melon (M. charantia): a review of efficacy and safety. Am J Health Syst Pharm 2003;60:356-9.

113. Dutta PK, Chakravarty AK, Chowdhury US, Pakrashi SC. Vicine, a Favism-inducing toxin from Momordica charantia Linn. seeds. Indian J Chem 1981;20:669-71.

114. Deshaware S, Gupta S, Singhal RS, Joshi M, Variyar PS. Debittering of bitter gourd juice using $\beta$-cyclodextrin: Mechanism and effect on antidiabetic potential. Food Chem 2018;262:78-85.

115. Tan SP, Kha TC, Parks SE, Stathopoulos CE, Roach PD. Effects of the spray-drying temperatures on the physiochemical properties of an encapsulated bitter melon aqueous extract powder. Powder Technol 2015;281:65-75.. 